\title{
Psiho- un neirotehnoloǵijas un sabiedriskās drošības problēmas
}

\author{
Andrejs Vilks \\ Rīgas Stradiña universitāte, Juridiskā fakultāte, Latvija
}

\section{Kopsavilkums}

Raksta autors publikācijā vēlas pievērst lasītāju uzmanību vienai no iespējamām jaunajām pieejām tiesībaizsardzības iestāžu darbībā - psiho- un neirotehnolog̣ijām -, kā arī autors pakavēsies pie minētās tēmas jaunākajām iezīmēm. Rakstā ir ieskicēti psihotehnoloğiskās izziṇas un ietekmēšanas daži aspekti, neirotiesībzinātnes (neirolaw) attīstības kontūras, kā arī psihotehnologijas studiju kursu realizēšanas prakse un iespējas juristu profesionālajā izglìtībā, nepretendējot uz tēmas plašu un dziḷu izklāstu.

Psiho- un neirotehnologiju izmantošana tiesību aizsardzības iestāžu darbībā ir pietiekami jauna. Vismaz Latvijas tiesiskajā, kā arī medicīniskajā pētniecības un praktiskajā darbībā. Tomēr speciālie dienesti atbilstīgas tehnologijas visai sekmīgi ir izmantojuši jau divdesmitā gadsimta sākumā. Kaut gan psihotehnolog̣iju izmantošanas vēsture ir krietni senāka. Pašreiz paredzamas daudz plašākas psihotehnologiju izmantošanas iespējas tiesību aizsardzības iestāžu darbībā.

Atslēgvārdi: sabiedriskā drošība, psihotehnologijas, neirotehnolog̣ijas, tiesībaizsardzības iestādes, noziedzība.

\section{levads}

Problēmas aktualitāte izpaužas nepieciešamībā apzināt minēto tēmu un tās izpētes iespējas, kas saistītas ar vairākām apstākḷu grupām.

Pirmkārt, ar jaunu noziedzīgo nodarījumu veidu, kā arī panēmienu izmantošanu, veicot kriminālās aktivitātes. Visai plaši ir pieejami dažādu metodiku apraksti ar personu psihiskās ietekmēšanas paṇēmieniem, ir izveidoti kursi indivīdu psihiskajā ietekmēšanā - psihotehniskie paṇēmieni tiek izmantoti veicot krāpšanas, īpašuma zādzības, ḷaunprātīgi izmantojot dienesta stāvokli. Psihotehnologijas tiek prasmīgi un aktīvi izmantotas, lietojot modernos tehniskos komunikācijas līdzekḷus (e-pastu, Skype, mobilos sakarus), veicot praktiski anonīmu saskarsmi u. c. 
Otrkārt, lai gan jaunās tehnologijas ir plaši pieejamas, tiesību aizsardzības iestāžu darbībā tās tiek izmantotas nepietiekami un nepilnīgi. Daudzos gadījumos tiesībaizsardzības struktūrās trūkst informācijas par šādām tehnolog̣ijām, to izmantošanas iespējām un rezultativitāti noziedzīgo nodarījumu novēršanā un apkarošanā, identificējot nodarījumus izdarījušās personas, vācot lietiskos pierādījumus, kā arī veicot noziedznieku psihokorekciju.

Treškārt, daži medicīniskie un starpdisciplinārie pētījumi un zinātnisko izstrāžu rezultāti, to skaitā neirologiijā, varētu sniegt pilnīgi jaunas iespējas personu izziṇā un vinu pretsabiedriskās un noziedzīgās uzvedības korekcijā.

Ceturtkārt, psihotehnologijas ir iespējams izmantot, pilnveidojot tiesību aizsardzības iestāžu vienotību, iekšējo mobilitāti, profesionalitāti, novēršot psihotraumatismu, "izdegšanu” un deformāciju.

Arī Latvijā psihotehnologiiju izmantošanā ir zināma pieredze. 2008. gadā Latvijas Policijas akadēmijas, Kriminālistikas katedrā tās vadītāja Dr. habil. iur. profesora A. Kavaliera vadībā tika sākta projekta izstrāde par noziegumu atklāšanu un nozīmīgas informācijas ieguvi, izmantojot hipnozi. Projekta sākuma posmā tika apzināta hipnozes izmantošana ārvalstu tiesiskajā praksē, hipnozes stāvoklī iegūtās informācijas izmantošana izmeklēšanas darbībās. [9]

Darba pamatmērḳis ir apzināt pašreizējo, galvenokārt ārvalstu tiesību aizsardzības iestāžu praksi, psiho- un neirotehnologiiju izmantošanas pieredzi.

Psihotehnologiju izmantošana noziedzīgo nodarījumu atklāšanā un novēršanā ir perspektīva, jo balstās uz tiesisko un medicīnisko pieeju, dod iespējas izstrādāt interdisciplināru lietošanas metodiku, kā arī sniedz atbalstu, pilnveidojot tiesiskās politikas vadlīnijas, uzlabojot tiesību aizsardzības iestāžu organizatorisko potenciālu. Pētījuma gaitā izstrādātie materiāli zināmā mērā jau tiek izmantoti jauno speciālistu - ārstu, juristu, psihologu, psihoterapeitu, sociālo darbinieku u. c. - izglìtošanā. Izstrādes rezultāti varētu attīstīt psihotehnoloǵiju izmantošanu noziedzīgo nodarījumu atklāšanā un novēršanā, apzināt psihotehnologiiju lietošanu no medicīniskā aspekta, izstrādāt to lietošanas metodiku, kā arī pilnveidot sociālo politiku, uzlabojot tiesībaizsardzỉbas iestāžu organizatorisko potenciālu.

\section{Noziedzīgos nodarījumus veic nevis cilvēki, bet viņu smadzenes}

Dažu valstu tiesiskajā praksē aizvien biežāk tiek izmantoti neirobiologiskie pētỉjumi, kas ḷauj liecināt ne tikai par indivīdu vainu izdarītajos noziedzīgajos nodarījumos, bet arī var atspēkot viṇu vainīgumu un minimizēt iespējas nevainīgas personas sodīšanai. Uz tiesas sēdēm par ekspertiem tiek uzaicināti neirologi, kuri izsaka viedokli par apsūdzēto psihisko stāvokli noziedzīgā nodarījuma izdarīšanas brīdī. Pēc Djuka universitātes profesores Naitas Farahani (Nita Farahany) domām (viņa vienlaikus ir arī ASV prezidenta Baraka Obamas padomniece bioētikas jautājumos), pašreiz ASV tiesās, 
kur tiek skatītas lietas par slepkavībām, neirologi tiek uzaicināti apmēram 5\% gadījumu no skatāmajām lietām. [7] Advokāti, izmantojot neirolog̣iskos izmeklējumus, cenšas pierādìt, ka viṇu klientu nežēlība, vardarbība un impulsivitāte ir izskaidrojama ar neirologiska rakstura novirzēm, kas izslēdz apsūdzēto vainīgumu. Ja 2005. gadā ASV pēc neirobiologu palīdzības advokāti vērsās 30 slepkavību lietās, tad 2012. gadā minētais radītājs jau sasniedza 100 gadījumus. Neirobioloǵiskie izmeklējumi biežāki ir noziegumos, kurus veic nepilngadīgie, jo viṇu psihofizioloğiskās iespējas kontrolēt savu uzvedību vēl neesot pilnīgi attīstìtas.

Advokāti arī izmanto neirobioloǵisko pētījumu rezultātus, kuri liecina par pusaudžu augsto ietekmējamību, runājot par paṇēmieniem, kas tiek izmantoti policijas izmeklēšanas procesā, iegūstot aizdomās turēto personu atzišanās liecības. Kopumā, advokāti tiesas izmeklēšanas procesā plaši izmanto argumentu, ka izdarītajos sevišḳi smagajos noziegumos noteicošais faktors ir apsūdzēto nekontrolējamās smadzenes un vinu psihiskie procesi.

\section{Cilvēku psihotehnoloǵiskā izziṇa un ietekmēšana}

Cilvēku psihotehnolog̣iskās ietekmes veidi ir diezgan dažādi. Psihotehnologiskā ietekme var būt diferencēta atkarībā no saskarsmes veida - tieša vai netieša; no izmantotajiem psihotehnologiskajiem līdzekḷiem - tehnologiska (tehnogēna), vizuāla, verbāla, mentāli energètiska; atkarībā no ietekmes objektu aptvēruma - individuālā, grupu, masveidīga; atkarībā no ietekmēšanas mērḳa - pozitīva, sociāli neitrāla, negatīva u. c.

Psihotehnologiskās ietekmēšanas rezultātā tiek veidota (programmēta) darbība, kuru indivīds nespēj kontrolēt. Ārstniecībā šādai ietekmei var būt pozitīva nozīme (novēršot indivīda depresīvo vai paaugstinātas agresivitātes stāvokli, ietekmējot atkarību pārtraukšanu utt.). Tomēr aizvien biežāk psihotehnologiskā (psihoenergétiskā) ietekme tiek izmantota pretēji cilvēku saprātīgajām interesēm (izstrādājumu, preču, pakalpojumu, kreditēšanas, reklāmas kampaṇu ekspansijai).

\section{Neirotehnoloǵijas tiesību aizsardzības vidē}

Neirotehnologiijas pēdējā desmitgadē attīstās sevišḳi strauji, kas ir saistīts ar jaunu cilvēka izpētes metožu izmantošanu, to skaitā - funkcionālās magnētiskās rezonanses tomogrāfijas, magnētiskās encilogrāfijas, elektroencilogrāfijas, infrasarkanās spektroskopijas, datortomogrāfijas un pozitronu emisijas tomogrāfijas lietošanu. RSU Psihosomatiskās medicīnas un psihoterapijas katedras pasniedzējs Artūrs Utināns atzīst, ka jaunās neirozinātnes var tikt izmantotas cilvēku individuālās uzvedības prognozēěanā, nosakot ieslodzīto paaugstinātas agresivitātes un antisociālas personības iezìmes. [10] Ar atbilstīgu tehnolog̣iju palīdzību būtu iespējams identificēt teroristus vai pat pedofilus. Izmantojot cilvēka domu rekonstruēšanu elektroniskajās sistēmas (Visual Image Reconstruction from Human Brain), ir iespējams lasìt cilvēka domas datorā. Neirovizualizācijas tehnologija ir izveidojusi pat jaunu nozari - neirojurisprudenci (neirolaw). 
Tiesiskajā un medicīniskajā praksē aizvien biežāk tiek lietota tā saucamā "smadzeñu pirkstu nospiedumu metode" (brain fingerprinting). Metodika dod iespējas atjaunot un vizualizēt atmiņu fragmentus, kuri ir saistìti ar cilvēka iepriekšējo darbību vai apstākḷiem, kādos viṇš ir atradies. Magnētiskā stimulācija sekmē smadzeṇu segmentu aktivizāciju. Veicot pārrunas ar indivīdu (aptauju, nopratināšanu), tiek noteikta viṇa reakcija uz noteiktiem vārdiem, frāzēm, attēliem, lietām. "Smadzeṇu pirkstu nospiedumu" tehnoloǵijas autors ir Lorens Faruels (Lawrence Farwell). Minētā metodika, kuras nosaukums ir Mermer, tika izmantota par pierādījumu ASV Aijovas štatā Terrija Haringtona lietā. [8] Sākotnēji vinsš tika apsūdzēts slepkavībā. Vēlāk, izmantojot "smadzeņu pirkstu nospiedumu" metodi, tika konstatēts, ka apsūdzētajam ir alibi, bet liecinieks, kurš sniedza liecību par T. Haringtonu, melo. "Smadzennu pirkstu nospiedumu" metode tika izmantota, pierādot sērijveida slepkavas Džeimsa B. Grindera vainu trīs sieviešu nogalināšanā. [4]

"Smadzeņu pirkstu nospiedumu" metodikas pamatā ir cilvēka smadzeṇu impulsīva reakcija zemapziņas līmenī uz ārējo stimulu 300 milisekundēs; piemēram, parādot indivīdam pazīstama cilvēka fotoattēlu, atbilstīgais smadzenuu segments to atpazīst. Smadzeṇu psihiskās reakcijas nav iespējams ietekmēt un kontrolēt. Testēšanas procesā nav nepieciešama indivīda verbāla atbilde. Uz pārbaudāmās personas galvas tiek izvietoti elektroniskie sensori, kas fiksē reakcijas un novada tās uz datoru. Stimuls, uz kuru reaǵē pārbaudāmā persona, var būt skaṇas, vārdi, attēli, smaržas, lietas, datorattēls (zīmes, simboli). Stimulu pazī̌sanas noliegums tikai pierāda testējamās personas negodigumu.

Neirojurisprudence ir jauna multidisciplināra zinātne, kura ietver tiesību zinātni un neirolog̣iju. Tās izziņas joma ir neirolog̣ijas atklājumu izmantošana jurisprudencē, pētot, analizējot un vērtējot tiesiska rakstura parādības, faktus un tiesību subjektu uzvedības modeḷus. Starptautiskajā terminologijā tiek lietoti tādi termini kā Legal Neuroscience, Law and Neuroscience, Neurolaw, Neurojurisprudence, kā arī Neurocriminology. Neirojurisprudencē tiek apzinātas iespējas un robežas, cik lielā mērā neirologijas secinājumi ir izmantojami tieslietās.

Neirojurisprudence un tās inovatīvās pieejas galvenokārt tiek lietotas kriminolog̣ijā, kriminālistikā un kriminālprocesā.

Kriminologiijas ietvaros apzinot individuālā noziedzīgā nodarījuma mehānismu, neirolog̣ijas līmenī ir iespējams izpētìt ārējās sociālās (mikro) vides apstākḷu iespaidu uz indivīda psihiskajiem procesiem, stāvokli un īpašībām. Kriminologijā būtiski ir izzināt neiroloğijas atzīmes par indivīda pretsabiedrisko orientāciju, noviržu un motīvu veidošanos. Ne mazāk nozīmīgi ir jautājumi par individuālās tiesiskās apzinnas un kultūras veidošanās procesu, tā deformāciju. Arvien vairāk neirologijas sasniegumi varētu būt izmantojami personu, kuras ir izdarījušas noziedzīgos nodarỉjumus, resocializācijā probācijas dienestā. Neirologijas metodikas varētu būt izmantojamas jaunpieṇemto tiesisko aktu akceptēšanā individuālā līmenī. 
Individuālo kriminālo aktu cēloṇus agrāk meklēja galvaskausa uzbūves anomālijās, cilvēka konstitucionālās uzbūves īpatnībās, hromosomu patalogiijās, genētiskās novirzēs. Neirolog̣iskā pieeja ir saistīta ar noziedzịgas uzvedības cēloṇu apzināšanu cilvēka smadzenēs, neironos.

Neirolog̣ijā ir izpētīta serotonīna ietekme uz cilvēka agresīvu vai depresīvu uzvedību. Serotonīns tiek raksturots kā mīlestības un laimes hormons, kas nosaka indivìda laimes sajūtu un indivīda labsajūtu, un emocionālo komfortu. Izpētes rezultāti liecināja, ka serotonīna līmeņa samazināšanās veicināja indivīdu paaugstinātu agresivitāti vai depresiju, kas varēja izmainīt suicīda izpausmes. Kā vardarbības pret apkārtējo vidi, kā arī autovardarbības (suicīdiem vai to mēǵinājumiem) ir vienots determinants serotonīna nepietiekamība cilvēka organismā.

Personām, kuras ir izdarījušas smagus noziegumus (slepkavības, smagus miesas bojājumus, izvarošanas u. c.), neirologiskā izpētē ir fiksēts pazemināts serotonīna lìmenis, lìdz ar to šādas personas, balstoties uz biologiskiem rādìtāiem, nespēj veikt tîšas, mērḳtiecīgas darbības. Pēc būtības viṇi pilnā mērā kontrolē savu uzvedību. Vinus varētu uzskatīt par dậeji pieskaitāmiem, un tiem var būt piemērots mazāks sods nekā personām, kurām serotonīns ir normālā līmenī.

Balstoties uz minēto pieeju, būtu vēlams apzināt, vai indivīdiem, kuri nodarījuši smagus noziegumus, ir iespējama medicinniskā izpēte, konstatējot viṇu serotonīna līmeni vai kontrolējot pazeminātu minētās vielas līmeni, vai ir iespējams noteikt viṇa pieskaitāmības pakāpi un spējas kontrolēt savu uzvedību. Kā apsekojums personām ar pazeminātu serotonīna līmeni ietekmēs soda noteikšanu?

ASV 2004. gadā tika sagatavots apkopojums par neirozinātnisko ietekmi un liecībām krimināltiesībās (An Overview of the Impact of Neiroscience Evidence in Criminal Law.). Apkopojums sastāv no šādām sadaḷām:

1) minētās atbildības nozīme krimināltiesībās;

2) procedūrjautājumiem par liecību sniegšanu kriminālprocesā;

3) neiroskenēšana un krimināltiesiskā prakse. [1]

Apkopojumā tiek atzīts, ka ASV tiesas aizvien biežāk tiesas izmeklēšanas gaitā izmanto smadzeņu skenēšanas dokumentus par zinātnisku pamatojumu procesa dalībnieku vainīgumam vai nevainīgumam. Tã lietā "ASV pret Erskinu" (United States vs. Erskine; 588 F, 2d, 721, 9th Cir., 1978) [5] Erskins tika apsūdzēts nepatiesu liecību sniegšanā teritoriālajai apdrošināšanas bankai. Apelācijas sūdzỉbu Erskins balstīja uz to, ka pirmās instances tiesa neaț̣āva atbildētājam pievienot liecībām viṇa smadzeṇu skenēšanas rezultātus, kuri liecināja par apsūdzētā nepietiekamajām mentālajām spējām, kas ietekmētu banku tās nepiemērotu lēmumu pieṇemšanā.

ASV apelācijas tiesa aț̣āva vēlāk pievienot Erskina smadzeṇu skenēšanas rezultātus, un tiesa tika pārskatìta.

Apkopojuma autori atzīst, ka būtu vēlams procesos iesaistītajām pusēm nepieciešamības gadỉjumos pieprasīt smadzeṇu skenēšanu personām, kuras tiek apcietinātas vai kā drošîbas līdzeklis tiek izvērtēts mājas arests, pārbaudot viṇu agresivitātes 
līmeni un bīstamību apkārtējiem iedzīvotājiem. Smadzeṇu skenējuma rezultāti ir nozīmīgi arī nosakot apsūdzēto vainas pakāpi un atbildības veidu.

Smadzeņu skenēšana tiek izmantota ne tikai ASV. 2013. gada jūnijā Indijā tiesa atzina par vainīgu kādu sievieti sava bijušā līgavaiṇa slepkavībā. Viṇai tika piespriests mūža ieslodzījums. Nekādi citi pierādỉjumi, kuri liecinātu par sievietes vainu, lietā fiksēti netika, izṇemot neirotehnologiskos sievietes smadzeṇu pètījumus. Pētỉjumā tika izmantota elektrisko smadzeṇu viḷnu izmaiṇu līknes analīzes metodika BEOS (Brain Electrical Oscillations Signature). Atbilstīgu pētijumu veica Indijas neirologs Čampadi Ramanoms Mukundanoms. [11]

BEOS metodika, balstoties uz encefalogrammas datiem, l̦auj noteikt, vai cilvēkam veidojas asociācijas un vai viņš domā par atsevišşu notikumu faktiem, kuri viṇam tiek atgādināti (stāstīti, rādīti). Zināmi fakti, darbība vai bezdarbība - tos atpazīstot, smadzenēs "izgaismojas" atsevišḳi segmenti, persona no jauna atceras izjusto un pārdzīvoto. Metodika tajā pašā laikā sniedz iespējas atškirirt, ko indivīds ir redzējis un ko darīiis. Tiek atzīts, ka minētā metodika arī palīdz noteikt, ko cilvēks plāno, tostarp viṇa pretsabiedriskās un kriminālās ieceres.

ASV prezidents Baraks Obama 2013. gada 2. aprīlī paziņoja, ka tiek uzsākta jauna zinātniskā programma "Cilvēka smadzeṇu izpēte, izmantojot inovatīvās neirotehnologijas" - BRAIN Initiative (Brain Research through Advancing Innovative Neurotechnologies). [2] Programmas mērḳis ir iegūt pilnu cilvēka smadzeṇu karti, kurā tiktu ietverti visi neironi un sinapses (neironu savienojumi). Programmas realizācijas terminš̌ - desmit gadi. Tās finansējums ir paredzēts kopš 2014. gada, pieškirot pirmatnējai tās izstrādei 100 miljonus ASV dolāru. 2013. gada nogalē bija jābūt gatavam programmas realizācijas plānam. Primārie programmas uzdevumi ir indivīdu dažādu slimību novēršana un ārstēšana (Parkinsona, epilepsijas un citu). Kā viens no iespējamiem projekta pasākumiem tika minēta palīdzības sniegšana posttraumatiskajiem militāro operāciju veterāniem, personām ar psihiskām saslimšanām. Perspektīvā tiek atzìts, ka datora programma atbilstīgu pētỉjumu rezultātā varēs reageèt uz cilvēku domām un izpausmes formām, valodas barjeras zudīs. Šajā pašā laikā sabiedrībā izskan pamatotas bažas, ka cilvēku domas, izjūtas un darbību varēs kontrolēt un korigèèt.

Arī Eiropas Savienības zinātniski pētnieciskās institūcijas ir vienojušās par cilvēka galvas smadzeṇu izpēti, realizējot projektu Human Brain Project. [6] 2013. gada oktobra sākumā Šveicē Eiropas 135 zinātniski pētniecisko iestāžu pārstāvji vienojās par desmitgadīga (2014-2023) projekta izstrādi. Projekta kopējās izmaksas 1,2 miljardi eiro.

Vēl 2012. gadā Lielbritānijas Karaliskā biedrība savā ziṇojumā pavēstīja, ka jaunākie pētījumi neirologiijas jomā tiks izmantoti brun,oto spēku un speciālo dienestu vajadzībām. [3] Neirolog̣iskās tehnologiijas tiek izmantotas jauniesaucamo karavīru testēšanā, lemjot jautājumu par viṇu nosūtī̌sanu dienestam atbilstīgākās bruṇoto spēku vienībās, dienesta gaitas novērošanā, kā arī pēctraumas rehabilitācijas procesā. Speciālisti atzīst, ka aizvien nozīmīgāki kḷūst jautājumi par tiesisko aktu pilnveidošanu, kas pilnīgāk spētu aizsargāt militārpersonas un civiliedzīvotājus no nelabvēlīgas psihotehnologiskās ietekmes. 


\section{Secinājumi}

Pašreizējās iespējas veikt no cilvēka gribas neatkarīgu viṇa izziṇu un iespējamās manipulācijas pieaug daudz straujāk nekā mēs to spējam apzināties. Jaunās tehnologiskās iespējas veicina cilvēka apdraudējumus. Tas nebūt nenozīmē, ka no jaunajām iespējām vispār būtu jāatsakās. Jauno tehnologiiju izmantošanā ir nepieciešams noteikt striktus tiesiskos pamatus un zinātniski objektīvu metodiku. Tehnologiju lietošanas mērḳiem un kārtībai ir jābūt morāli un ētiski sabiedrībā atbalstāmiem.

\section{Psycho and Neuro-technology and Public Safety Problems}

\section{Abstract}

The current capacity for the human beyond the control of his statement and possible manipulation is growing much faster than we are able to realize. New technological capabilities contribute to human threats. This does not mean that new capabilities are to be resigned form. Use of new technologies is necessary to identify legal basis and strict scientific methodology conversion lens. Technology use goals and policies have to be morally and ethically community assisted.

Keywords: public safety, psycho-technology, neuro-technology, law establishment, crime.

\section{Literatūra}

1. An Overview of the Impact of Neiroscience Evidence in Criminal Law. Iegūts no: http://bioethics.georgetown.edu/pcbe/background/neuroscience_evidence.html

2. BRAIN Initiative. Iegūts no: http://www.whitehouse.gov/share/brain-initiative

3. Brain Wawes Module 3. Conflict and Sesurity. Iegūts no: https://royalsociety.org/policy/ projects/brain-wawes/conflict-security

4. Farwell Brain Fingerprinting Catches a Serial Killer. Iegūts no: http://www.lawrencefarwell. com/Fairfield-Ledger-serial-killer-dr-larry-farwell-brain-fingerprinting-dr-lawrence-farwell. html

5. Glimcher, P. W. The neurobiology of individual decision making, dualism, and legal accountability in Engel, C., and Singer, W. (eds.), 2008. Better Than Conscious? Implacations for Performance and Institutiona Analysis, Strüngmann Forum Report 1, Cambridge, MA, MIT p. 341 Press. Iegūts no: http://www.decisionsrus.com/documents/the-neurobiology-of-individual-decision-making-dualism-and-legal-accountability.pdf

6. Human Brain Project. Iegūts no: https://www.humanbrainproject.eu/ 
7. Jean-Laurent, Cassely. C'est pas moi, c'est mon cerveau: les avocats américains abusent des neurosciences. Iegūts no: http://www.slate.fr/life/79941/avocats-defense-neurosciences.

8. Larry Farwell - Inventor of Brain Fingerprinting. Iegūts no: http://www.larryfarwell.com/ brain-fingerprinting-executive-summary-dr-larry-farwell-dr-lawrence-farwell.html

9. Miḳelsons, U. Kriminālistiskā hipnoze. Juridiskie un metodiskie aspekti. Rīga, 2008. Iegūts no: http://www.eksperts.gold.lv/Kriminalistiska_hipnoze.pdf

10. Kavalieris, A. Hipnozes izmantošana policijas aptaujā. Rīga: Latvijas Policijas akadēmija, 2009.

11. Utināns, A. Neirozinātnes policijas darbā. Iegūts no: http://www.rsu.lv/images/stories/dokumenti/zinu_pielikumi/Programma_un_tezes_13092013_RED_GALA.pdf

12. Нейротехнологии отправили человека за решетку. Iegūts no: http://www.mobiledevice.ru/ brain-electrical-oscillations-signature-beos-champadi-raman-muku.aspx 